\title{
The Cyclin Dependent Kinase Inhibitor Protein 21 Cytoplasmic Expression Depressing the Apoptosis of Human Bronchial Epithelial Cell
}

\author{
Zou Guoming*, Xiao Zuke \\ Email address: \\ georgezgm@163.com (Zou Guoming),634900720@qq.com (Xiao Zuke) \\ ${ }^{*}$ Corresponding author
}

Respiratory and Critical Medical Department, Jiangxi Provincial People's Hospital, Nanchang, China

\section{To cite this article:}

Zou Guoming, Xiao Zuke. The Cyclin Dependent Kinase Inhibitor Protein 21 Cytoplasmic Expression Depressing the Apoptosis of Human Bronchial Epithelial Cell. International Journal of Clinical and Developmental Anatomy. Vol. 6, No. 2, 2019, pp. 1-7. doi: 10.11648/j.ijcda.20200601.12

Received: June 15, 2019; Accepted: December 10, 2019; Published: January 8, 2020

\begin{abstract}
AIMS: To investigate the cytoplasmic $\mathrm{P}^{21}$ expression regulating the apoptosis of human bronchial epithelial cell. MOTHEDS: The relationship of the cytoplasmic $\mathrm{P}^{21}$ expression with the apoptosis of $16 \mathrm{HBE}$ cells was studied after the plasmid pEGFP-N1-p21 was transfected into the 16HBE cells. After the 16HBE cells was the stimulated by the TGF- $\beta 1$, the cytoplasmic and nucleic $\mathrm{P}^{21}$ expression and the apoptosis of $16 \mathrm{HBE}$ cell was detected, then the relationship of the $\mathrm{P}^{21}$ expression with the apoptosis of 16HBE cells was studied. RESULTS: The 16HBE cell had the basic low cytoplasmic and mainly high nucleic $\mathrm{P}^{21}$ protein expression, the plasmid $\mathrm{P}^{\mathrm{EGFP}-\mathrm{N} 1-\mathrm{p} 21}$ could express $\mathrm{P}^{21}$ protein only in the cytoplasm of $16 \mathrm{HBE}$ cell and did not affect the nucleic $\mathrm{P}^{21}$ protein level. The apoptosis of $16 \mathrm{HBE}$ cells after transfection of the $\mathrm{P}^{\mathrm{EGFP}-\mathrm{N} 1 \text {-p21 }}$ decreased. The apoptosis of 16HBE cells decreased as the time of the $\mathrm{P}^{\mathrm{EGFP}-\mathrm{N} 1-\mathrm{p} 21}$ transfection increased, but the apoptosis of $16 \mathrm{HBE}$ cells increased without the $\mathrm{P}^{\mathrm{EGFP}-\mathrm{N} 1-\mathrm{p} 21}$ transfection. The stimulation by TGF- $\beta 1$ led to the expression of the cytoplasmic and nucleic $\mathrm{P}^{21}$ proteins, but mainly the cytoplasmic $\mathrm{P}^{21}$ protein expression, as the stimulation concentration of TGF- $\beta 1$ increased, the cytoplasmic $\mathrm{P}^{21}$ expression decreased, but the nucleic $\mathrm{P}^{21}$ did not change. The apoptosis of $16 \mathrm{HBE}$ cells increased as the cytoplasmic $\mathrm{P}^{21}$ expression decreased after the concentration of TGF- $\beta 1$ stimulation increased. CONCLUSIONS: The apoptosis of $16 \mathrm{HBE}$ cell was inhibited by the high cytoplasmic $\mathrm{P}^{21}$ expression through the transfection of $\mathrm{P}^{\mathrm{EGFP}-\mathrm{N} 1 \mathrm{p} 21}$. TGF- $\beta 1$ stimulation promoted the apoptosis of $16 \mathrm{HBE}$ cell by inhibiting the cytoplasmic $\mathrm{P}^{21}$ expression. The cytoplasmic $\mathrm{P}^{21}$ expression depresses the apoptosis of $16 \mathrm{HBE}$ cells.
\end{abstract}

Keywords: Cyclin Dependent Kinase Inhibitor $\mathrm{P}^{21}$, Transforming Growth Factor- $\beta 1$, Apoptosis

\section{Introduction}

The apoptosis and the inflammation interact with each other to lead to occurrence, development of lung diseases [1]. The apoptosis is a complex procedure regulated by many factors including the cyclin dependent kinase inhibitor protein $21\left(\mathrm{P}^{21}\right)$ and cytokine as transforming growth factor$\beta 1$ (TGF- $\beta 1)[2,3]$. In cancer and other premature cells $\mathrm{P}^{21}$ inhibits the cell cycles to make cells apoptosis and death when highly expressing in the nuclei of these cells and inhibits the cells apoptosis when highly expressing in the cytoplasm of these cells [4]. In earlier researches $\mathrm{P}^{21}$ was found highly expressing in the smoker, $\mathrm{s}$ alveolar macrophages, airway epithelial cells and asthmatic bronchial epithelial cells and the expression of $\mathrm{P}^{21}$ correlated with the apoptosis these cells $[3,5]$. The earlier researches did not study the relationships of cell apoptosis with the $\mathrm{P}^{21}$ expression in cytoplasm or in nuclear in the lung cells. Transforming growth factor (TGF)- $\beta$ family proteins are multifunctional cytokines that have been implicated in the pathogenesis of diverse biologic processes including cell growth and survival, cell and tissue differentiation, development, inflammation, immunity, hematopoiesis, and tissue remodeling and repair [6]. TGF- $\beta_{1}$ can induce apoptosis through $\mathrm{P}^{21}$ [7]. There haven't studies about the relationship of the cytoplasmic $\mathrm{P}^{21}$ expression and the cell 
apoptosis under the stimulation of TGF- $\beta 1$. This research has studied the relationship of the $\mathrm{P}^{21}$ cytoplasmic expression with the apoptosis in the human bronchial epithelial cell $16 \mathrm{HBE}$ and that under the stimulation by TGF- $\beta 1$.

\section{Materials and Methods}

\subsection{Cell Recovery and Culture}

The human epithelial cell line 16HBE (The Experimental Medical Research Center, Guangzhou Medical University, China) was recovered from the liquid nitrogen vessel and cultured in the Dulbecco's modified Eagle's medium (high glucose) supplemented with $10 \%$ fetal bovine serum (Gibco) at $37^{\circ} \mathrm{C}$ and $5 \% \mathrm{CO}_{2}$.

\subsection{Preparation of the Plasmid}

The plasmid $\mathrm{P}^{\text {EGFP-N1-p21 }}$ purchased from the Shang Hai Invitrogen Corporation was amplified in the Escherichia coli and extracted according to the structures of the endotoxin free Plasmid Extraction kit (OMEGA Corporation).

\subsection{Transfection and Analysis of the Expression of the Plasmid P ${ }^{E G F P-N 1-p 21}$}

The experiment groups included the groups of the blank, the empty plasmid and the plasmid $\mathrm{P}^{\mathrm{EGFP}-\mathrm{N} 1-\mathrm{p} 21}$. The transfection processes were done according to the structures of the Lipofactamine 2000 transfection kit (American Invitrogen Corporation) with some modifications. The 12 holes transfection plate was used and each experiment group had 4 holes. The $5 \times 10^{5} 16 \mathrm{HBE}$ cells were planted in the each transfection hole. The quality of the plasmid was $8 \mu \mathrm{g}$.

After the transfection, the expressions of $\mathrm{P}^{\mathrm{EGFP}-\mathrm{N} 1-\mathrm{p} 21}$ were checked by the analysis of the mRNA and the protein of $\mathrm{P}^{21}$ in the nuclear and the cytoplasm. The total RNA was extracted according to the structures of the RNA Extracted Kit and the c-DNA was synthesized with the primer 5'CCGTGGGAAGGTAGAGCTTG 3'. The 20ml reaction mixture included the total RNA $5 \mu 1,2 \times$ TS Reaction Mix $10 \mu$ 1, RT/RI Mix $1 \mu 1$, ribonuclease free $\mathrm{H}_{2} \mathrm{O} 4 \mu 1$ was incubated at the $42^{\circ} \mathrm{C}$ for $30 \mathrm{mins}$ and heated at the $85^{\circ} \mathrm{C}$ for $5 \mathrm{mins}$. After the c-DNA synthesized, the RT-PCR of $\mathrm{P}^{21}$ mRNA was conducted together with the control of $\beta$-actin. The $\mathrm{P}^{21}$ primer was 5'GACTGTGATGCGCTAATGGC 3'and the reverse primer was 5'CCGTGGGAAGGTAGAGCTTG 3'. The $50 \mu \mathrm{l}$ TR-PCR reaction mixture included cDNA $2 \mu \mathrm{l}, \mathrm{P}^{21}$ primers $1 \mu \mathrm{l}, \beta$-actin primers $1 \mu \mathrm{l}, 10 \times$ buffer $5 \mu \mathrm{l}$, dNTPs $4 \mu \mathrm{l}$, DNA-polymerase $0.5 \mu \mathrm{l}$, ddH2O $29.5 \mu \mathrm{l}$. The PCR reaction conditions were pre-denaturation at $94^{\circ} \mathrm{C} 30 \mathrm{~s}$, splitting at $94^{\circ} \mathrm{C} 5 \mathrm{~min}$, annealing at $60^{\circ} \mathrm{C} 30 \mathrm{~s}$, extending at $72^{\circ} \mathrm{C} 30 \mathrm{~s}$, 35 circles, extending at $72^{\circ} \mathrm{C} 10 \mathrm{~min}$. The PCR reaction products were electrophoresised, the bands of $\mathrm{P}^{21}$ and $\beta$-actin cDNA were scanned by BIO-RAD, the ratio of the gray levels of the bands of $\mathrm{P}^{21}$ and $\beta$-actin cDNA represented the levels of the $\mathrm{P}^{21}$ mRNA.

\subsection{Stimulation to the Human Epithelial Cell Line 16HBEs by $T G F-\beta 1$}

The $1-5 \times 10^{6} 16 \mathrm{HBE}$ cells were cultured in the 6 holes culture plates. Before the stimulation, the cells were cultured in the DMEM with $0.5 \%$ FBS for 12 hours. The TGF- $\beta 1$ at the concentrations of $0 \mathrm{ng} / \mathrm{ml}, 3 \mathrm{ng} / \mathrm{ml}, 10 \mathrm{ng} / \mathrm{ml}$ were added into the different $5 \times 10^{6} 16 \mathrm{HBE}$ cells for $12 \mathrm{~h}, 24 \mathrm{~h}$.

\subsection{Analysing the Cell Apoptosis by Flow Cytometry}

The single cell suspension of $16 \mathrm{HBE}$ cells was centrifuged at $2000 \mathrm{rmp}$ for $5 \mathrm{~min}$. According to the structures of apoptosis kit, the cell aggregations were mixed with 500ul Binding Buffer, 5ul Annexin-FITC, 5ul PI light. The mixtures reacted at room temperature for 10 minutes. The apoptosis was detected by flow cytometry. The excitation light wave length of the fluorescent dye was $488 \mathrm{~nm}$, and the emission light wave length was 530nm. The results showed that the lower left quadrant was living cells, the lower right quadrant was early apoptotic cells, the right upper quadrant was late apoptotic and dead cells, and the left upper quadrant was dead cells.

\subsection{Checking the Expression of $P^{21}$ in the Cytoplasm and the Nuclear}

The cytoplasm and nuclear proteins were extracted according to the structures of the cytoplasm and nuclear protein extraction kits (Sigma). The expression of $\mathrm{P}^{21}$ was detected by the Western-blot. The electrophoretic gel was made up with $15 \%$ separation gel and 5\%concentration gel. The denatured $\mathrm{P}^{21}$ samples mixed with $5 \times$ SDS buffer and the pre-stained protein Makers of $7 \mathrm{ul}$ at one side and $3 \mathrm{ul}$ at the other side were added into the electrophoretic gel pores. The electrophoresis was conducted at $80 \mathrm{~V}$ before the dye got into the concentration gel and conducted at $120 \mathrm{~V}$ when the dye got into the separation gel. After the end of electrophoresis, the concentration gel was removed and the separation gel was soaked in the transfer buffer. The PVDF membrane was soaked in the methanol for $30 \mathrm{~s}$, placed in the transfer buffer. The transfer membrane sandwich of the filter paper-PVDF film - gel - filter paper from the anode to the cathode stacked was placed in the wet transfer instrument board. The electrical transfer was conducted at $276 \mathrm{~mA}$ constant current for 90min. After electrical transfer, the PVDF film was immersed and slowly swayed in the sealing solution containing 5\% skim milk powder for 2 hours. After sealing, the PVDF film was taken out and immersed into the solution with the mouse anti- $\mathrm{P}^{21}$ monoclonal antibody (1: 1000) and mouse anti- $\beta$-tubulin monoclonal antibody (1: 1200), swayed at $4{ }^{\circ} \mathrm{C}$ overnight. At the second day the PVDF film was taken out and washed with the TBST solution10minfor 3 times, then immersed into the solution with goat anti-mouse fluorescence antibody (1:5000) and swayed at room temperature for $2 \mathrm{~h}$. The PVDF film with the antibodies was washed with TBST 10min for three times. The PVDF film with the antibodies was added with ECL fluorescent agent and exposed with machine. The results of Western blot were 
analyzed by image $\mathrm{J}$ analysis system, the ratios of gray value of target protein band to the reference protein band represented the quantities of the target protein.

\subsection{Statistical Analysis}

SPSS17.0 statistical software package was used for the data analysis. The measurement data were expressed by mean \pm standard deviation $(\mathrm{M} \pm \mathrm{S})$. Paired $\mathrm{t}$ test was used for paired data and the single factor variance analysis (one-wayAVOVA) was used to compare the multiple sample means. The means of within and among groups was compared with LSD method. The difference between the groups was statistically significant by $\mathrm{P}<0.05$.

\section{Results}

\subsection{The Gene Expression of the Plasmid $P^{E G F P-N 1-p 21}$ Being Transfected into $16 \mathrm{HBE}$}

After the transfection, the expression of the $\mathrm{P}^{\text {EGFP-N1-p21 }}$ was checked by RT-PCR. The electrophoresis results of $\mathrm{P}^{\mathrm{EGFP}-\mathrm{N} 1-\mathrm{p} 21}$ and $\beta$-actin CDNA was presented in the Figure 1 and the table 1 . This result presented that the $16 \mathrm{HBE}$ cell had the basic low cytoplasmic and mainly high nucleic $\mathrm{P}^{21}$ protein expression, the plasmid $\mathrm{P}^{\text {EGFP-N1-p21 }}$ could express $\mathrm{P}^{21}$ protein only in the cytoplasm of $16 \mathrm{HBE}$ cell and did not affect the nucleic $\mathrm{P}^{21}$ protein level.

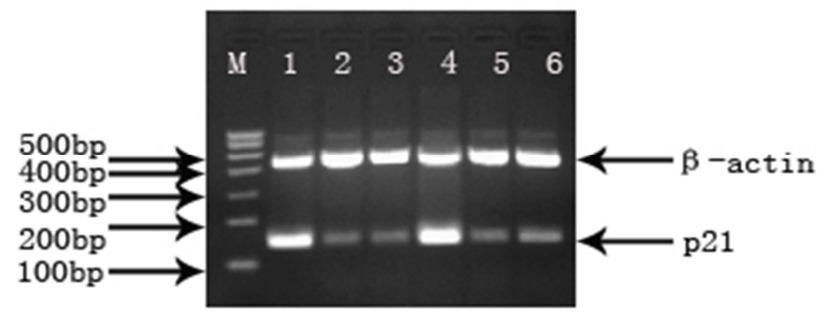

Figure 1. The electrophoresis bands of the $P^{E G F P-N 1-p 21}(1,4)$, the $P^{E G F P}(2,5)$ and the blank $(3,6)$. the left band: 100bp DNA mark.

Table 1. The quantitative analysis of the $m R N A$ expressions of the $P^{E G F P-N 1-p 21}$ after transfection.

\begin{tabular}{llll}
\hline & $\mathbf{P}^{\text {EGFP-N1-p21 }}$ & $\mathbf{P}^{\text {EGFP }}$ & blank \\
\hline $\mathrm{p} 21 / \beta$-actin & $1.34 \pm 0.048$ & $0.18 \pm 0.032$ & $0.19 \pm 0.037$ \\
$\mathrm{~F}$ & & 1078.852 & \\
$\mathrm{P}$ & & 0.000 & \\
\hline
\end{tabular}

Table 1 The difference of the expressions of the $\mathrm{P}^{\text {EGFP-N1-p21 }}$ group, the $\mathrm{P}^{\mathrm{EGFP}}$ group and the blank was statistically significant $(\mathrm{P}<0.05)$. The expression of the $\mathrm{P}^{\mathrm{EGFP}-\mathrm{N1} 1 \mathrm{p} 21}$ group was statistically significant compared with the expression of the $\mathrm{P}^{\mathrm{EGFP}}$ group and the blank $(\mathrm{P}<0.05)$, the difference of expression of the $\mathrm{P}^{\mathrm{EGFP}}$ group was not statistically significant compared with the blank $(\mathrm{P}>0.05)$.

\subsection{The Expression of the Protein of Plasmid $P^{E G F P-N 1-p 21}$ Being Transfected Into $16 \mathrm{HBE}$}

After the transfection, the cytoplasmic and nuclear $\mathrm{P}^{21}$ proteins of the plasmid $\mathrm{P}^{\text {EGFP-N1-p21 }}$, the plasmid $\mathrm{P}^{\mathrm{EGFP}}$ and the blank were extracted respectively and checked by Westernblot. The Western-blot results of $\mathrm{P}^{21}$ proteins were presented in the Figure 2. The comparisons of the relative quantities of the cytoplasmic and nuclear $\mathrm{P}^{21}$ proteins were presented in the Table 2. These results showed the $16 \mathrm{HBE}$ cell had the basic low cytoplasmic and mainly high nucleic $\mathrm{P}^{21}$ protein expression, the plasmid $\mathrm{P}^{\mathrm{EGFP}-\mathrm{N} 1-\mathrm{p} 21}$ could express $\mathrm{P}^{21}$ protein only in the cytoplasm of $16 \mathrm{HBE}$ cell and did not affect the nucleic $\mathrm{P}^{21}$ protein level.

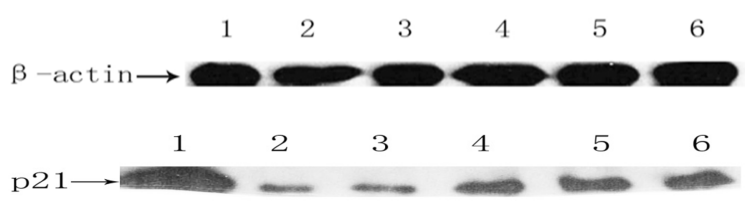

Figure 2. The Western-blot results of $P^{21}$ proteins after transfection: 1 the cytoplasmic $P^{21}$ protein of plasmid $P^{E G F P-N 1-p 21} .2$ the cytoplasmic $P^{21}$ protein of the plasmid $P^{E G F P} .3$ the cytoplasmic $P^{21}$ protein of the blank. 4 the nucleic $P^{21}$ protein of plasmid $P^{E G F P-N 1-p 21} .5$ the nucleic $P^{21}$ proteins of the plasmid $P^{E G F P} .6$ the nucleic $P^{21}$ protein of the blank.

Table 2. The quantitative analysis of the protein expressions of the $P^{E G F P-N I-}$ ${ }^{p 21}$ after transfection.

\begin{tabular}{lllll}
\hline \multirow{2}{*}{ groups } & \multicolumn{2}{l}{ Protein $\mathbf{P}^{\mathbf{2 1}}$ expression } & \multirow{2}{*}{$\mathbf{t}$} & \multirow{2}{*}{$\mathbf{p}$} \\
\cline { 2 - 3 } & cytoplasmicP & nuclear $\mathbf{P}^{\mathbf{2 1}}$ & & \\
\hline $\mathrm{P}^{\text {EGFP-N1-p21 }}$ & $1.74 \pm 0.102^{*}$ & $0.41 \pm 0.096$ & 20.859 & 0.002 \\
$\mathrm{P}^{\text {EGFP }}$ & $0.20 \pm 0.053$ & $0.42 \pm 0.122$ & 5.349 & 0.033 \\
blank & $0.19 \pm 0.073$ & $0.40 \pm 0.094$ & 11.981 & 0.007 \\
$\mathrm{~F}$ & 383.989 & 0.049 & & \\
$\mathrm{P}$ & 0.000 & 0.952 & & \\
\hline
\end{tabular}

Table 2 The difference of the cytoplasmic protein levels of the $\mathrm{P}^{\mathrm{EGFP}-\mathrm{N} 1-\mathrm{p} 21}$ group, the $\mathrm{P}^{\mathrm{EGFP}}$ group and the blank was statistically significant $(\mathrm{F}=383.989, \mathrm{P}<0.05)$, and the difference of the nuclear protein levels of the $\mathrm{P}^{\mathrm{EGFP}-\mathrm{N} 1-\mathrm{p} 21}$ group, the $\mathrm{P}^{\mathrm{EGFP}}$ group and the blank was not statistically significant $(\mathrm{F}=0.049, \mathrm{P}>0.05)$. In the $\mathrm{P}^{\mathrm{EGFP}-\mathrm{N} 1-\mathrm{p} 21}$ group the cytoplasmic $\mathrm{P}^{21}$ level was higher than the nucleic protein level $(\mathrm{t}=20.859, \mathrm{P}<0.05)$. In the $\mathrm{P}^{\mathrm{EGFP}}$ and the blank group the cytoplasmic $\mathrm{P}^{21}$ protein level was lower than the nucleic protein level $(\mathrm{t}=5.349, \mathrm{P}<0.05 ; \mathrm{t}=11.981$, $\mathrm{P}<0.05)$.

\subsection{Analyzing the Apoptosis of 16HBE After the Transfection of Plasmids}

After the transfection by the plasmids for 24hous and 48hours, the16HBE cells were collected to analyze apoptosis by the flow cytometry. The percentages of apoptosis were present in the right lower quadrant of the results in the Figure 3 and Figure 4. The comparisons of the percentages of apoptosis were presented in the Table 3. These results showed that the apoptosis of $16 \mathrm{HBE}$ cells after transfection of the $\mathrm{P}^{\mathrm{EGFP}-\mathrm{N1} \text {-p21 }}$ decreased. Combining the results of 3.2, it was found that the apoptosis of $16 \mathrm{HBE}$ cells decreased as the time of the $\mathrm{P}^{\mathrm{EGFP}-\mathrm{N1} \text {-p21 }}$ transfection increased, but the apoptosis of $16 \mathrm{HBE}$ cells increased without the $\mathrm{P}^{\mathrm{EGFP}-\mathrm{N} 1-\mathrm{p} 21}$ transfection. 


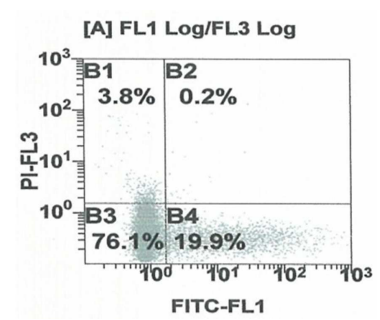

[A] FL1 Log/FL3 Log
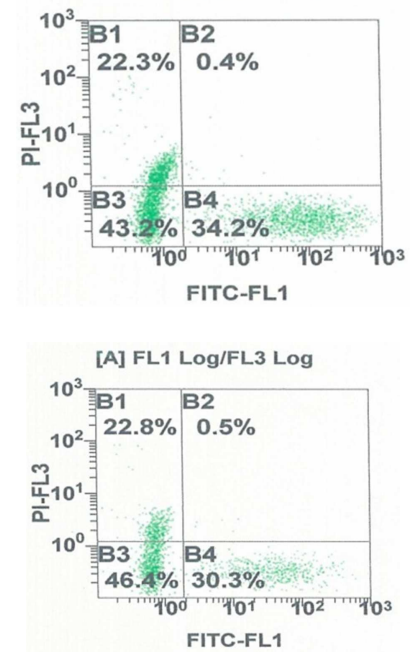

Figure 3. The percentages of apoptosis were presented in the B4 region by the flow cytometry 24 hours after transfection. From the left to the right were the results of the $P^{E G F P-N 1-p 21}$ group, the $P^{E G F P}$ group and the blank group.
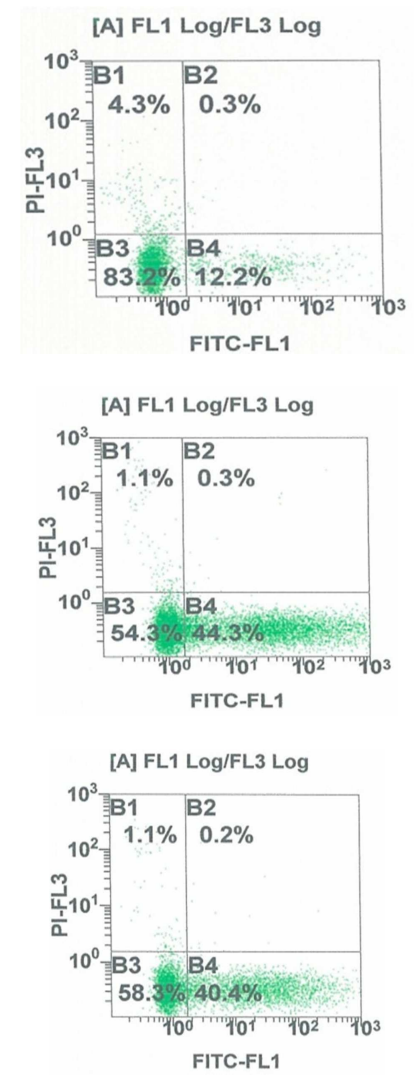

Figure 4. The percentages of apoptosis were presented in the $B 4$ region by the flow cytometry 48 hours after transfection. From the left to the right were the results of the $P^{E G F P-N I-p 21}$ group, the $P^{E G F P}$ group and the blank group.
Table 3. The quantitative analysis of apoptosis of the 16HBE cells after the transfection of $P^{E G F P-N I-p 21}$

\begin{tabular}{lllll}
\hline \multirow{2}{*}{ groups } & \multicolumn{2}{l}{ Transfection time } & \multirow{2}{*}{$\mathbf{t}$} & \multirow{2}{*}{$\mathbf{p}$} \\
\cline { 2 - 3 } & $\mathbf{2 4 h}$ & $\mathbf{4 8 h}$ & & 0.036 \\
$\mathrm{P}^{\mathrm{EGFP-N1-p21}}$ & $0.22 \pm 0.031^{\#}$ & $0.14 \pm 0.025^{*}$ & 17.889 & 0.033 \\
$\mathrm{P}^{\mathrm{EGFP}}$ & $0.35 \pm 0.010$ & $0.45 \pm 0.003$ & 19.000 & 0.037 \\
blank & $0.31 \pm 0.008$ & $0.42 \pm 0.017$ & 17.333 & \\
$\mathrm{~F}$ & 23.464 & 187.265 & & \\
$\mathrm{p}$ & 0.015 & 0.001 & & \\
\hline
\end{tabular}

Table 3 The difference of the percentages of apoptosis of the $\mathrm{P}^{\text {EGFP-N1-p21 }}$ group, the $\mathrm{P}^{\mathrm{EGFP}}$ group and the blank after 24 hours and 48 hours transfection were statistically significant ( $\# \mathrm{~F}=23.464, \quad \mathrm{P}<0.05 ; \mathrm{F}=187.265, \quad \mathrm{P}<0.05)$. The percentages of apoptosis of the $\mathrm{P}^{\mathrm{EGFP}-\mathrm{N} 1-\mathrm{p} 21}$ group were lower than that of the $\mathrm{P}^{\mathrm{EGFP}}$ group and the blank group after 24hours and 48 hours transfection $(\mathrm{P}<0.05)$, but the percentages of apoptosis of the $\mathrm{P}^{\mathrm{EGFP}}$ group were same as that of the blank group after 24 hours and 48 hours transfection $(\mathrm{P}>0.05)$. In the $\mathrm{P}^{\mathrm{EGFP}-\mathrm{N} 1-\mathrm{p} 21}$ group the percentages of apoptosis after 48hours transfection was lower than that after 24 hours transfection $(\mathrm{t}=17.889, \mathrm{P}<0.05)$. In the $\mathrm{P}^{\mathrm{EGFP}}$ group and the blank group the percentages of apoptosis of 48 hours transfection was higher than that of 24 hours transfection $(\mathrm{t}=19.000, \mathrm{P}<0.05 ; \mathrm{t}=17.333, \mathrm{P}<0.05)$.

\subsection{Analyzing the Apoptosis of $16 \mathrm{HBE}$ After the Stimulation by TGF- $\beta 1$}

After the stimulation by TGF- $\beta 1$ for 12 hous and 24 hours, the $16 \mathrm{HBE}$ cells were collected to analyze apoptosis by the flow cytometry. The percentages of apoptosis were present at the right lower quadrant of the results in the Figure 5, Figure 6 , and Figure 7 (partly). Through the comparison of the percentages of apoptosis in the Table 4 , it was found that at the same stimulation time the percentages of apoptosis increased as the stimulation concentrations of TGF- $\beta 1$ increased and that at the same stimulation concentrations of TGF- $\beta 1$ the percentages of apoptosis increased as the stimulation time increased. These results suggested that the stimulation of TGF- $\beta 1$ promoted the $16 \mathrm{HBE}$ cells apoptosis.

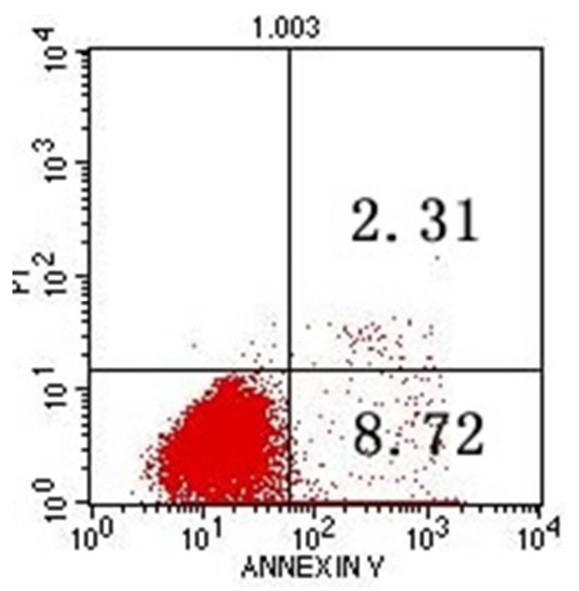

Figure 5. The results of the apoptosis without the stimulation of TGF- $\beta 1$ after the 24hours were presented at the right lower quadrant. The value was average of the percentages of the apoptosis. 


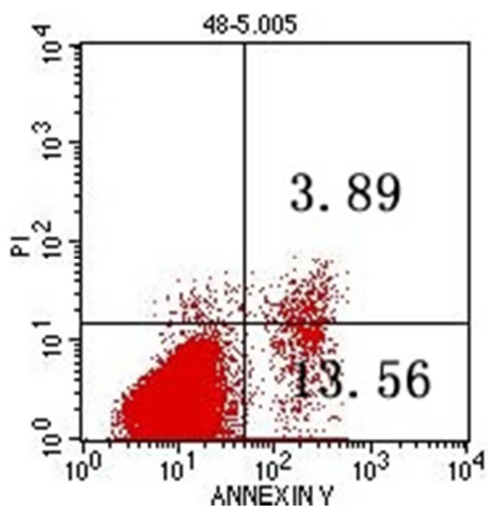

Figure 6. The results of the apoptosis with the stimulation of TGF- $\beta 1$ $(10 \mathrm{ng} / \mathrm{ml})$ after the 12 hours were presented at the right lower quadrant. The value was average of the percentages of the apoptosis.

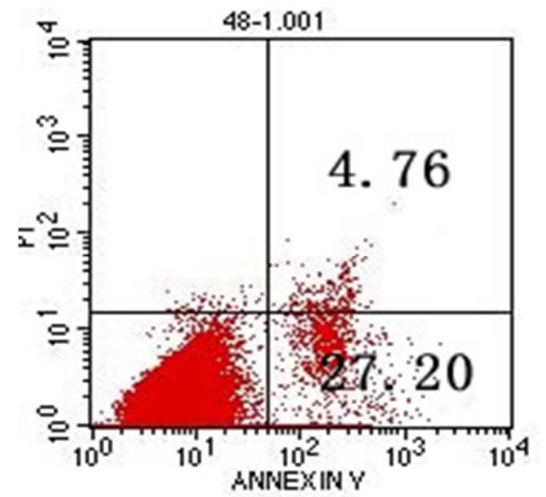

Figure 7. The results of the apoptosis with the stimulation of TGF- $\beta 1$ $(10 \mathrm{ng} / \mathrm{ml})$ after the 24 hours were presented at the right lower quadrant. The value was average of the percentages of the apoptosis.

Table 4. The quantitative analysis of apoptosis of the $16 H B E$ cells after the TGF- $\beta 1$ stimulation.

\begin{tabular}{lllll}
\hline \multirow{2}{*}{$\begin{array}{l}\text { TGF- } \boldsymbol{\beta}_{\mathbf{1}} \\
\text { ng/ml }\end{array}$} & \multicolumn{2}{l}{ Stimulation time } & \multirow{2}{*}{ t } & P \\
\cline { 2 - 3 } & $\mathbf{1 2 h o u r s}$ & $\mathbf{2 4}$ hours & & \\
\hline 0 & $6.7 \pm 0.47$ & $8.74 \pm 1.02$ & 3.64 & 0.068 \\
3 & $9.86 \pm 0.49$ & $13.51 \pm 0.80$ & 20.24 & 0.002 \\
10 & $16.00 \pm 0.50$ & $27.16 \pm 1.60$ & 16.6 & 0.004 \\
$\mathrm{~F}$ & 297.40 & 194.499 & & \\
$\mathrm{P}$ & 0.00 & 0.00 & & \\
\hline
\end{tabular}

Table 4 The difference of the percentages of apoptosis of the groups of $0 \mathrm{ng} / \mathrm{ml} \mathrm{TGF}-\beta 1,3 \mathrm{ng} / \mathrm{ml}$ TGF- $\beta 1$ and $10 \mathrm{ng} / \mathrm{ml}$ TGF- $\beta 1$ after 12 and 24hours stimulation were statistically significant $(\mathrm{F}=297.40, \mathrm{P}<0.05 ; \mathrm{F}=194.499, \mathrm{P}<0.05)$. At the same stimulation time the differences of the percentages of apoptosis of the groups of $0 \mathrm{ng} / \mathrm{ml}$ TGF- $\beta 1,3 \mathrm{ng} / \mathrm{ml}$ TGF$\beta 1$ and $10 \mathrm{ng} / \mathrm{ml}$ TGF- $\beta 1$ were statistically significant compared with each other $(\mathrm{P}<0.05)$. In the group of $0 \mathrm{ng} / \mathrm{ml}$ TGF- $\beta 1$ the percentages of apoptosis after 24 hours stimulation was same as that after 12 hours stimulation $(t=3.64, P>0.05)$. In the group of $3 \mathrm{ng} / \mathrm{ml} \mathrm{TGF-} \beta 1$ the percentages of apoptosis after 24hours stimulation was higher than that after 12 hours stimulation $(\mathrm{t}=20.24, \mathrm{P}<$ $0.05)$. In the group of $10 \mathrm{ng} / \mathrm{ml}$ TGF- $\beta 1$ the percentages of apoptosis after 24hours stimulation was higher than that after 12 hours stimulation $(\mathrm{t}=16.6, \mathrm{P}<0.05)$.

\subsection{The Expression of the Protein of $P^{21}$ After the

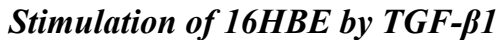

After the stimulation by TGF- $\beta 1$ for 24 hours, the cytoplasmic and nuclear $\mathrm{P}^{21}$ proteins of the groups of $0 \mathrm{ng} / \mathrm{ml}$ TGF- $\beta 1, \quad 3 \mathrm{ng} / \mathrm{ml}$ TGF- $\beta 1$ and $10 \mathrm{ng} / \mathrm{ml}$ TGF- $\beta 1$ were extracted respectively and tested by Western-blot. The results were presented at the Figure 8. The comparisons of the relative quantities of the cytoplasmic and nucleic $\mathrm{P}^{21}$ proteins of the groups of $0 \mathrm{ng} / \mathrm{ml}$ TGF- $\beta 1,3 \mathrm{ng} / \mathrm{ml}$ TGF- $\beta 1$ and $10 \mathrm{ng} / \mathrm{ml}$ TGF- $\beta 1$ were presented in the table 5 . These results showed that the stimulation by TGF- $\beta 1$ led to the expression of the cytoplasmic and nucleic $\mathrm{P}^{21}$ proteins, but mainly the cytoplasmic $\mathrm{P}^{21}$ protein expression. As the stimulation concentration of TGF- $\beta 1$ increased, the cytoplasmic $\mathrm{P}^{21}$ expression decreased, but the nucleic $\mathrm{P}^{21}$ did not change.

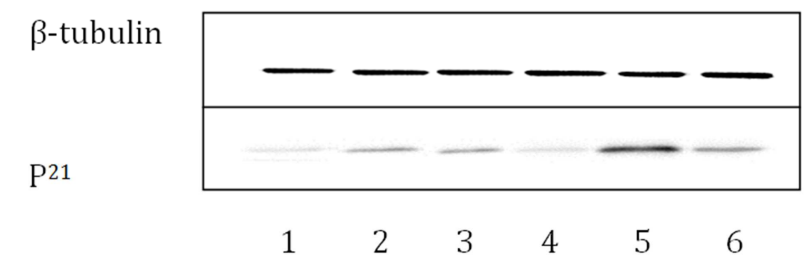

Figure 8. The Western-blot results of $P^{21}$ proteins after the stimulation of $T G F-\beta 1$. The Western-blot results of $\beta$-tubulin were the control. 1. the result of nuclear $P^{2 I}$ protein with the stimulation of $0 \mathrm{ng} / \mathrm{ml}$ TGF- $\beta 1$ 2. the result of nuclear $P^{21}$ protein with the stimulation of $3 n g / m l ~ T G F-\beta 13$. the result of nuclearP $P^{21}$ protein with the stimulation of $10 \mathrm{ng} / \mathrm{ml} T G F-\beta 1$ 4. the result of cytoplasmic $P^{21}$ protein with the stimulation of $0 \mathrm{ng} / \mathrm{ml}$ TGF- $\beta 1$ 5. the result of cytoplasmic $P^{21}$ protein with the stimulation of $3 n g / m l T G F-\beta 1$ 6. the result of cytoplasmic $P^{21}$ protein with the stimulation of $10 \mathrm{ng} / \mathrm{ml}$ TGF- $\beta 1$.

Table 5. The quantitative analysis of the expression of $P^{21}$ of the $16 \mathrm{HBE}$ cells 24 hours after the TGF- $\beta 1$ stimulation.

\begin{tabular}{lllll}
\hline $\begin{array}{l}\text { TGF- } \boldsymbol{\beta 1} \\
(\mathbf{n g} / \mathbf{m l})\end{array}$ & $\mathbf{P}^{\mathbf{2 1}}$ & \multicolumn{2}{l}{$\mathbf{t}$} & $\mathbf{P}$ \\
\cline { 2 - 3 } & $\mathbf{N u c l e a r}^{\mathbf{2 1}}$ & $\mathbf{C y t o p l a s m i c} \mathbf{P}^{\mathbf{2 1}}$ & & \\
\hline 0 & $0.10 \pm 0.02$ & $0.11 \pm 0.015$ & 0.87 & 0.480 \\
3 & $0.26 \pm 0.03$ & $1.13 \pm 0.07$ & 23.53 & 0.002 \\
10 & $0.27 \pm 0.02$ & $0.35 \pm 0.04$ & 5.24 & 0.035 \\
& 58.03 & 377.22 & & \\
& 0.001 & 0.000 & & \\
\hline
\end{tabular}

Table 5 The difference of the cytoplasmic and nuclear $\mathrm{P}^{21}$ levels of the groups of $0 \mathrm{ng} / \mathrm{ml}$ TGF- $\beta 1,3 \mathrm{ng} / \mathrm{ml}$ TGF- $\beta 1$ and $10 \mathrm{ng} / \mathrm{ml}$ was statistically significant $(\mathrm{F}=58.03, \mathrm{P}<0.05$; $\mathrm{F}=377.22, \mathrm{P}<0.05)$. The nuclear $\mathrm{P}^{21}$ levels of the group of $3 \mathrm{ng} / \mathrm{ml} \mathrm{TGF}-\beta 1$ and the group of $10 \mathrm{ng} / \mathrm{ml} \mathrm{TGF}-\beta 1$ were higher than that of group $0 \mathrm{ng} / \mathrm{ml}$ TGF- $\beta 1(\mathrm{P}<0.05)$, but the difference of the nuclear $\mathrm{P}^{21}$ levels of the group of $3 \mathrm{ng} / \mathrm{ml}$ TGF- $\beta 1$ and the group of $10 \mathrm{ng} / \mathrm{ml}$ TGF- $\beta 1$ was not statistically significant $(\mathrm{P}>0.05)$. The cytoplasmic $\mathrm{P}^{21}$ levels of the group of $3 \mathrm{ng} / \mathrm{ml} \mathrm{TGF-} \beta 1$ and the group of $10 \mathrm{ng} / \mathrm{ml}$ TGF- $\beta 1$ were higher than that of group of $0 \mathrm{ng} / \mathrm{ml}$ TGF- $\beta 1$ (P $<0.05, \mathrm{P}<0.05)$, the cytoplasmic $\mathrm{P}^{21}$ levels of the group of $10 \mathrm{ng} / \mathrm{ml} \mathrm{TGF}-\beta 1$ was lower than the group of $3 \mathrm{ng} / \mathrm{ml}$ TGF- $\beta 1$ $(\mathrm{P}<0.05)$. In the group of $0 \mathrm{ng} / \mathrm{ml}$ TGF- $\beta 1$ the cytoplasmic $\mathrm{P}^{21}$ protein level was same as the nuclear $\mathrm{P}^{21}$ level $(\mathrm{t}=0.87$, $\mathrm{P}>0.05)$. In the group of $3 \mathrm{ng} / \mathrm{ml}$ TGF- $\beta 1$ the cytoplasmic $\mathrm{P}^{21}$ level was higher than the nucleic $\mathrm{P}^{21}$ level $(\mathrm{t}=23.53, \mathrm{P}<$ 
$0.05)$. In the group of $\mathrm{T} 10 \mathrm{ng} / \mathrm{ml}$ GF- $\beta 1$ the cytoplasmic $\mathrm{P}^{21}$ protein level was higher than the nuclear protein level $(\mathrm{t}=5.24, \mathrm{P}<0.05)$.

\subsection{Analyzing the Relationship of Expression of the Protein of $P^{21}$ and the Apoptosis of $16 \mathrm{HBE}$ After the Stimulation by TGF-ק1}

Combining the results of 3.4 and 3.5 , it was found that the protein $\mathrm{P}^{21}$ mainly expressed in the cytoplasm of the $16 \mathrm{HBE}$ cells after the TGF- $\beta 1$ stimulation, the apoptosis of $16 \mathrm{HBE}$ cells increased as the cytoplasmic $\mathrm{P}^{21}$ expression decreased after the concentration of TGF- $\beta 1$ stimulation increased.

\section{Conclusions}

The apoptosis of $16 \mathrm{HBE}$ cell was inhibited by the high cytoplasmic $\mathrm{P}^{21}$ expression through the transfection of $\mathrm{P}^{\mathrm{EGFP}}$ N1-p21. TGF- $\beta 1$ stimulation promoted the apoptosis of $16 \mathrm{HBE}$ cell by inhibiting the cytoplasmic $\mathrm{P}^{21}$ expression. The cytoplasmic $\mathrm{P}^{21}$ expression depresses the apoptosis of $16 \mathrm{HBE}$ cells.

\section{Discussions}

Katsuyuki Tomita et al found that $\mathrm{P}^{21}$ expressed highly in the alveolar macrophages and airway epithelial cells of smoking patients and localized predominantly to the cytoplasm and protect the apoptosis of these cells, while in the normal macrophages and airway epithelial cells $\mathrm{P}^{21}$ localized predominantly to the nuclear [3]. Sarah M. Puddicombe et al found that $\mathrm{P}^{21}$ expressed highly in asthmatic bronchial epithelial cells, distributed mainly in the nuclear of normal and mild asthmatic bronchial epithelial cells, and in cytoplasm of severe asthmatic bronchial epithelial cells [5]. Thus the sub-cell expression of $\mathrm{P}^{21}$ interacts with the function of human bronchial epithelial cell. $\mathrm{P}^{21}$ is regarded as a modulator of apoptosis, Cytoplasmic p21 leads to an inhibition of multiple caspases and apoptotic effectors including pro-caspase-3, caspase- 8 , caspase-10, apoptosis signal-regulating kinase 1 and stress-activated protein kinase, Paradoxically, p21 can also promote apoptosis [8-10]. These different functions may be related to phosphorylation of some sites of $\mathrm{P}^{21}$ protein and its subcellular localization of cytoplasm and nuclear $[4,11,12]$. In this study, the plasmid $\mathrm{P}^{\text {EGFP-N1-p21 }}$ was transfected into the human bronchial epithelial cell. It was found that $\mathrm{P}^{\text {EGFP-N1-p21 }}$ only expressed in the cytoplasm of normal bronchial epithelial cell and protected the apoptosis of normal bronchial epithelial cell. These results were consistent with other earlier researches, but were more direct to explain the mechanism of the cytoplasm expression of $\mathrm{P}^{21}$ protected the apoptosis of human bronchial epithelial cell and were helpful to study the mechanism in the clinical condition.

Transforming growth factor (TGF- $\beta$ ) family proteins are multi-functional cytokines that have been implicated in the pathogenesis of diverse biologic processes including cell growth and survival, cell and tissue differentiation, development, inflammation, immunity, hematopoiesis, and tissue remodeling and repair [6]. $\mathrm{P}^{21}$ functioning as transcription factor/co-factor is essential for TGF- $\beta$ mediated breast cancer cell migration and invasion, high $\mathrm{P}^{21}$ expression was correlated with poor overall and distant metastasis free survival of breast cancer patients promoting migration/invasion at the transcriptional level [13, 14]. In accordance with this, another study with a breast cancer mouse model has shown that invasion is accompanied by an up-regulation of $\mathrm{P}^{21}$ pointing to its role in a "reciprocal switching between proliferation and invasion" [15]. Masashi Yamasakiet al demonstrated that $\mathrm{P}^{21}$ inhibited the TGF- $\beta_{1}$ induced apoptosis in the mouse airway epithelial cells [7]. Sarah M. Puddicombe et al found that the cell cyclin inhibitory activity of $\mathrm{P}^{21}$ was intimately associated with its nuclear localization upon TGF- $\beta$ treatment [5]. In our study, we found that after treating the human bronchial epithelial cell with TGF- $\beta$, the expressions of the nuclear $\mathrm{P}^{21}$, but mainly the cytoplasmic $\mathrm{P}^{21}$ increased and as the increasing of the concentrations of the TGF- $\beta$ treatment, the expressions of cytoplasmic $\mathrm{P}^{21}$ decreased, the expressions of nuclear $\mathrm{P}^{21}$ did not change. We also found that after treating the human bronchial epithelial cell with TGF- $\beta$, the apoptosis was induced and as the increasing of the concentrations of the TGF- $\beta$ treatment, the apoptosis increased. The apoptosis of 16HBE cells increased as the cytoplasmic $\mathrm{P}^{21}$ expression decreased after TGF- $\beta 1$ stimulation.

From this research we found that the cytoplasmic expressions of $\mathrm{P}^{21}$ inhibited the apoptosis of human bronchial epithelial and that TGF- $\beta 1$ could induced the apoptosis of human bronchial epithelium through decreasing the cytoplasmic $\mathrm{P}^{21}$ expression. This is one important mechanism of lung diseases. Cytoplasmic localization of $\mathrm{P}^{21}$ could be a reliable biomarker and a promising intervention target.

\section{References}

[1] Uhal B. D. Apoptosis in lung fibrosis and repair [J]. Chest, 2002, 122, 293S-298S.

[2] Daisuke Arai, Norihiro Nomura, Kunihiko Fukuchi et al. Cytoplasmic localization of cyclin kinase inhibitor p21 delays the progression of apoptosis [J]. Cancer Genomics \& Proteomics, 2006, 3, 29-38.

[3] Katsuyuki Tomita, Gaetano Caramori, Sam Lim, et al. Increased $\mathrm{p} 21^{\mathrm{cip} 1 / \text { wafl }}$ and $\mathrm{b}$ cell lymphoma leukemia- $\mathrm{x}_{1}$ expression and reduced apoptosis in alveolar macrophages from smokers [J]. American Journal of Respiratory and Critical Care Medicine, 2002, 166, 724-731.

[4] AraiD., Nomura N., Fukuchi K., et al. Cytoplasmic localization of cyclin kinase inhibitor p21 delays the progression of apoptosis [J]. Cancer Genomics \& Proteomics, 2006, 3, 29-38.

[5] Puddicombe S. M., Carlos T. L., Richter A. Increased expression of $\mathrm{p} 21^{\text {waf }}$ cyclin-dependent kinase inhibitor in asthmatic bronchial epithelium [J]. American Journal of Respiratory Cell and Molecular Biology. 2003, 28, 61-68. 
[6] Blobe GC, Schiemann WP, Lodish HF. Role of transforming growth factor beta in human disease. N Engl J Med 2000, 342, $1350-1358$

[7] Yamasaki M., Kang HR, Homer R. J., et al. p21 regulates TGF- $\beta_{1}$-induced pulmonary responses via a TNF- $\alpha$ signaling pathway [J]. American Journal of Respiratory Cell and Molecular Biology, 2008, 38, 346-353.

[8] Gartel, A. L.; Tyner, A. L. The role of the cyclin-dependent kinase inhibitor $\mathrm{P}^{21}$ in apoptosis. Mol. Cancer Ther [J]. 2002, $1,639-649$.

[9] Gartel, A. L. The conflicting roles of the cdk inhibitor p21 (CIP1/WAF1) in apoptosis [J]. Leuk. Res. 2005, 29, 1237 1238 .

[10] Asada M, Yamada T, Ichijol H, et al. The role of $\mathrm{P}^{21}$ in apoptosis, proliferation, cell arrest and antioxidant activity in URB-irradiated human HacaT keratinocytes [J]. Med SCI Monit Basic Rec, 2015, 21, 86-95.

[11] Karimian A, Ahmadi Y, Yousefi B. Multiple functions of p21 in cell cycle, apoptosis and transcriptional regulation after DNA damage [J]. DNA Repair, 2016, 42, 63-71.

[12] Huang YF, Wang WM, Chen YS, et al. The opposite prognostic significance of nuclear and cytoplasmic p21 expression in resectable gastric cancer patients. J Gastroenterol [J], 2014, 49, 1441-52.

[13] Dai M, Al-Odaini AA, Arakelian, A, et al. A novel function for $\mathrm{p} 21 \mathrm{Cip} 1$ and acetyltransferase $\mathrm{p} / \mathrm{CAF}$ as critical transcriptional regulators of TGFbeta-mediated breast cancer cell migration and invasion. Breast Cancer Res [J], 2012, 14, R127.

[14] Dai M, Al-Odaini AA, Fils-Aime N, et al. Cyclin D1 cooperates with $\mathrm{p} 21$ to regulate TGFbeta-mediated breast cancer cell migration and tumor local invasion. Breast Cancer Res [J]. 2013, 15, R49.

[15] Qian X, Hulit J, Suyama K, et al. p21CIP1 mediates reciprocal switching between proliferation and invasion during metastasis [J]. Oncogene 2013, 32, 2292-2303. 